\title{
The Problems between the Rights and Obligations of Vaccine Covid-19 for the People of Indonesia
}

\author{
Evi Oktarina ${ }^{1}$, Evita Isretno Israhadi ${ }^{2}$ \\ \{Evioktasrina255@gmail.com¹, evita_isretno@borobudur.ac.id ${ }^{2}$ \} \\ Universitas Borobudur Jakarta, Indonesia ${ }^{1,2}$
}

\begin{abstract}
The government through the Deputy Minister of Law and Human Rights said that the vaccination Covid-19 is the duty of all citizens to realize the public health. Then the responsibility of the state plays a role in meeting the needs of the vaccine Covid-19 for the entire community to remember in a state of emergency which if people are not able to buy the vaccine is not likely to be the victims of the ferocity of Covid-19. The research aims to analyze on how the vaccine Covid-19 can be enjoyed by the whole people of Indonesia and whether the vaccine Covid-19 is a right or obligation to the people of Indonesia. The examination technique utilized in this exploration is regulating legitimate exploration exact, in particular the strategy for regularizing lawful examination which is then upheld with the expansion of the information or the components of the observational.
\end{abstract}

Keywords: Rights and Obligations; the Responsibility of the State; Vaccination

\section{Introduction}

Pandemic Covid-19, swept across the country in the world by the year 2020 to change the order of human life in all parts of the world, including the country of Indonesia beloved. Mankind is forced to adapt to new habits. In Indonesia, habits-new habits are reflected in some of the rooms with the presence of 'my Mother' which contains obligations 3M (Wear a mask, Keep the distance and Wash your hands with soap) for the community, as well as 3T (Testing, Tracing, Treatment) for the Government.

On the basis of the various efforts made by the Government by issuing policies to mitigate them. The policy, Restrictions on Large-Scale Social (PSBB), which refers to Law No. 6 of 2018 on Health Quarantine as revised by State Regulation Number 21 of the Year 2020 regarding PSBB in order to accelerate the treatment of Covid-19, is one of the semilockdowns known. Other policy social distancing, physical distancing imposed for the people of Indonesia since March 2020, made various appeals from the President, heads of state institutions, community leaders, both through print and electronic media. Various policy packages issued by the government expected a potent tackling the spread of Covid-19, however the fact that the level of public awareness for these policies is still relatively low.

Another attempt to handling Covid-19 in various of the world, has conducted a research in order to manufacture a vaccine or drugs to cope with Covid-19. With regard to the vaccine, there are a number of brands a vaccine for Covid-19 that have been made. Indonesia itself 
using a number of brands of vaccines in order to handling Covid-19 in Indonesia, namely Sinovac, Novavax, Covax/Gavi, AstraZeneca, and Pfizer. The vaccine than as a commodity with economic value, have the aspect of the law is no less important in protecting as intellectual work of human. A vaccine that has been protected through legal instruments in the end should not be other people use it carelessly without the permission of the inventor (inventor) vaccine. Violations of the top things that a person can deal with the legal issues that may not only experience a loss of material but also immaterial.

The government through the Minister of Health stated that has distributed 1.2 million doses of the vaccine Covid-19 to 34 (thirty-four) of the provinces throughout Indonesia as of January 7,2021 . While the implementation of vaccination is planned to be conducted in the second week of January 2021, after the issuance of the permit emergency use or Emergency Use Authorization by the FDA (Food and Drug Supervisory Agency). The advantages and disadvantages of immunization in Indonesia in the community are discussed. A lot of people have questioned whether public vaccination is a right or a responsibility. The government, through the Deputy Minister of Law and Human Rights, stated that it is the responsibility of all residents to realize public health through immunization Covid-19. Many human rights activists, on the other hand, have said unequivocally that the freedom to refuse vaccinations is a fundamental human right.

Then the responsibility of the state plays a role in meeting the needs of the vaccine Covid19 for the entire community to remember in a state of emergency which if people are not able to buy the vaccine is not likely to be the victims of the ferocity of Covid-19. In addition, people also questioned the effectiveness of the vaccine Covid-19 with a pretext as not effective, the issue of conspiracy, causing side effects and others. Even there are areas that states that people who refuse the vaccine Covid-19 will be subject to a fine. In view of the foundation referenced above, in this paper will be examined about: how the immunization Covid-19 can be appreciated by the entire individuals of Indonesia and regardless of whether the antibody Covid-19 is a right or commitment to individuals of Indonesia?

\section{Research Methods}

The research technique utilized in this study is normative legal research empirical, which is a form of normative legal research that is then supplemented with data or empirical aspects. In the method of research is a normative-empirical is also on the implementation of the provisions of normative legal in action every legal event certain to happen in a society.

\section{Results and Discussion}

\subsection{Covid-19 is a Vaccine that May be Enjoyed by the Whole Indonesian Population}

Pandemic Covid-19 may not be unpunished if you do not want the human population will be depleted due to the ferocity of the virus. The spread of the Covid-19 would thus be able to be forestalled or basically decreased by a person with all the strength of consistent endeavors. A vaccination might be investigated as a way to halt the virus from spreading. The Indonesian government continues to encourage the scientists epidomologi to do research. However, the vaccine is not easily and then can be distributed. That the vaccine is a primary need, when viewed from an economic perspective, then the vaccine is a commodity that will have a high 
selling value. On the basis of it is the reason why countries are racing to produce a vaccine Covid-19 because it will generate a profit of abundant.

Vaccine Covid-19 as a commodity in the field of economic necessarily need to be protected with the legal instruments that use or sale of the vaccine is limited. This is because the vaccine as a product that is produced researchers have deservedly given the award. Researchers in the process of doing research has been utilizing the mind, time, energy, even cost up can then produced the vaccine. Vaccine products as outputs the results of such research in the treasures of the science of law is commonly referred to as Intellectual Property (IP). The legal protection of the vaccine Covid-19 as an IP that is if human thought into a thing that ought to be considered. The correct functioning of the law as an instrument of social construction, as pioneered by Roscoe Pound, is split into three categories of goals, among others: first, the interests of the country as one of the legal entities as the public interest. Second, the interests as a country as guard the interests of the social (social interest). Third, interest in the individual consists of the private. The vaccination's protection Covid-19 is extremely significant to the notion of legal protection as a means of better respecting human Rights in the public, social, and personal interests.

On this basis, Indonesia has a responsibility in terms of carrying out various efforts and policies issued. Peter Salim revealed that the terminology of responsibility in the legal sciences has three things, namely, liability, responsibility, and accountability. First, the liability that is a legal responsibility which is usually manifested in the form of the responsibility of civil. Second, the responsibility that comes from the word "response" which means action to respond to an issue or issues, and ability that means the ability or in other words "come bear the burden". Third, the accountability that is often associated with financial problems or related issues of a trust against certain agencies related to finance. Obligation with regards to this paper is identified with the obligation that both the obligation according to the pandemic and the satisfaction of the immunization Covid-19.

As we can see in the fourth paragraph of the Preface of the Constitution act of Indonesia Year 1945, the satisfaction of the vaccine Covid-19 becomes the comprehensive government's responsibility as just a type embodies the government's purpose: protect all Indonesians and the entire homeland of Indonesia, promote the general welfare, the intellectual life of the nation, and participate in implementing power structure free and equal, peaceful solution, and social justice. The responsibility of it will not be easy to be implemented if the vaccine Covid19 have been protected through intellectual property. This is due to the IPR give exclusive rights to the holders or owners of such rights. The exclusivity of the person/party that would make, use, sell, import, rent, lease, assign, or offers for sale or rent or submitted need a permit.

The intervention of the state as a form of responsibility the government has the characteristics of different models of patent protection. In terms of protection through the patent, then the government can realize the responsibility through the application of compulsory licensing. License means a form of the right to perform one or a series of actions or deeds given by their authorities in the form of a permit. If such permission is not obtained, then the act or acts committed such an act against the law.

General license can still be further divided into two, namely the exclusive license and nonexclusive. Agreement that merely added the promise of more of the licensor not to enter into agreements similar to the other party, commonly known by the exclusive license. While non select can be perceived that the licensee has no privileges against outsiders and the licensee couldn't avoid the understanding sub-permit, so that the licensor can be uninhibitedly gone into a permit concurrence with the other party once more. Permit in the patent was known the two licenses (see the Patent Law), necessary authorizing can be deciphered as an authorization 
to have the option to complete a patent with the particular reasons given by the public authority, as that will be the creator of audit of related licenses on immunization Covid-19. Under Patent Law Article 81 referenced that mandatory authorizing is one of the types of the permit is non-restrictive necessary.

Compulsory license can be granted in two categories of applicants, namely the Government (or Government agency or a third party authorized by the state) and third party other personal. The application of compulsory licensing by the government or a third party not necessarily can be given, but must be with a specific reason, among others, due to the urgent need of a state or situation and the condition of the extremes of others or the interests of the community not for commercial use. In an effort to anticipate if the Patent Holder or licensee to carry out a Patent in a form and in a manner detrimental to the interests of the community in agreement with Article 82 section (1) of the Patent Law; as an attempt to produce a pharmaceutical product that was granted a Patent in Indonesia to the treatment of diseases in humans based on Article 93 paragraph (1) of the Patent Law; as an attempt to import the procurement of pharmaceutical production, which was granted a Patent in Indonesia, but can not be produced in Indonesia in order to the treatment of diseases in humans, Article 93, paragraph (2) of the Patent Act.

The reason as mentioned above, it can certainly be used as a basis for the intervention of the state in realizing the responsibility of the state as a form of presence of the state in tackling Covid-19 through the implementation of compulsory licensing. The responsibility of the state through state intervention in the event of such now can not be negotiable to realize the purpose of the state, especially as the applicant's compulsory license if Indonesia as the recipient of the license. It is in harmony with Article 8 of the TRIPs which states that member states may set or change the law and regulation of their use, in order to define the size of the protection needed for the health of the community.

\subsection{Vaccine Covid-19 as the Right or the Obligation for Society}

Article 1 passage 1 of Law Number 36 Year 2009 on Health, expressed wellbeing is a solid state, both physical, mental, profound and social that permits everybody to live socially and financially useful, because of its wellbeing is the premise of the acknowledgment level of mankind. In this way, wellbeing is one of the sizes notwithstanding the degree of instruction and the economy, which decide the nature of HR (Human Development Index). As a basic liberty to wellbeing has been perceived and controlled in different global instruments. The best acknowledgment of the right to wellbeing, for example:

a. Article 25 Universal Declaration of Human Rights (UDHR);

b. Article 6 and 7 International Covenant on Civil and Political Rights (ICCPR);

c. Article 12 International Covenant on Economic, Social and Cultural Right (ICESCR);

d. Article 5 International Convention on the Elimination of All Forms of Racial Discrimination (ICERD);

e. Article 11, 12 and 14 Convention on the Elimination of All Forms of Discrimination against Women (Women's Convention);

f. Article 1 Convention against Torture and Other Cruel, Inhuman or Degrading Treatment or Punishment (Torture Convention, or CAT);

g. Article 24 Convention on the Rights of the Child (Children's Convention, or CRC).

Every human being since the birth of the bear rights and obligations which is free and rights. State formation and the holding power of a state must not reduce the meaning of freedom and the rights of humanity. The protection and respect for human rights is a pillar that 
is very important in any state referred to as state law. If in a country, human rights are neglected or violated by the accident and the suffering it causes can not be addressed in a fair, then the relevant country can not be called as a state of law in the real sense. Sacred insurance of the right to emotional wellness is reflected in Article $28 \mathrm{H}$ section (1) of the constitution of the Republic of Indonesia Year 1945, states that "everybody has the option to carry on with a prosperous life deep down and apparently, daily routines and acquire a decent experiencing climate and sound and has the option to get wellbeing administrations"

With respect to the commitments of the state identified with that in Article 34 section (3) which expresses that "the State is liable for the arrangement of medical care offices and public help offices which are commendable". This shows that the right to wellbeing, including psychological wellness are secured intrinsically. For privileges identifying with wellbeing, then, at that point, the state has a commitment to satisfy these freedoms. Concerning the treatment of the pandemic of Covid-19 in Indonesia, the Government has made strides to ensure the wellbeing of residents. Beginning from the build up the situation with the wellbeing crisis through Presidential Decree No. 11 of the Year 2020 on the Determination of Emergency Public Health Corona Virus Disease 2019 (Covid-19), complete the commitments of the Government to do 3T (testing, following, treatment), assemble crisis medical clinic even to do limitations on the assortment of the locale as specified in Government Regulation Number 21 of the Year 2020 on the Limitation of Large-Scale Social In Order to speed up the Handling of the Corona Virus Disease 2019 (Covid-19).

One of different endeavors being directed by the Government to secure the soundness of the residents of the territory of Indonesia is the execution of inoculation has been begun on January 13, 2021 with the beneficiary of the primary antibody is the President of the Republic of Indonesia, Joko Widodo. One of the issues of the law relating to vaccination is whether vaccination to the public is a right or obligation. As mentioned in the introduction section that a number of activists firmly states that refused the vaccine is the rights of the people. They are using the legal basis of Article 5 paragraph (3) of Law Number 35 Year 2009 on Health which expresses that "everybody has the privilege to freely and dependably decide their own wellbeing administrations that are important for himself'. However, when assessed based on the condition of the state of Indonesia in the pandemic Covid-19, the implementation of vaccination can be a thing that is compulsory. There are a number of reasons, namely:

a. When it is examined, Article 5 paragraph (3) of Law Number 36 Year 2009 on Health, indeed gives the right to every person in terms of determining their own health services that are necessary for him. However, when viewed in the context of the handling of the outbreak, especially in the pandemic Covid-19, there are 2 (two) other Laws to determine whether vaccination is right or obligation. The first is Article 14 paragraph (1) of Law No. 4 of 1984 about Outbreaks of Infectious Diseases which states that "whoever intentionally obstructs the implementation of the prevention of the plague as stipulated in this Law, will be rebuffed by a greatest detainment of 1 (one) year or potentially fines as high as Rp. 1.000.000, - (1,000,000 rupiah)". Second, Article 93 of Law No. 6 Of 2018 on Health Quarantine which expresses "Each individual who doesn't follow the execution of Health Quarantine alluded to in Article 9 section (1) and additionally upset the execution of Health Quarantine causing the Emergency Public Health will be rebuffed by a greatest detainment of 1 (one) year as well as a most extreme fine of all things considered Rp. $100.000 .000,00$ (100,000,000 rupiah)". While Article 9 of the Law a quo expressed that, "(1) Each individual will consent to the execution of Health Quarantine, (2) Any individual who is obliged to take an interest in the execution of Health Quarantine". 
If seen in the context of the conditions in Indonesia, which has announced a state of emergency health through Presidential Decree No. 11 of the Year 2020 on the Determination of Emergency Public Health Corona Virus Disease 2019 (Covid-19) and if the process of vaccination is available ways (at the moment) in order to reduce the rate of transmission of Covid-19, then the Law Number 36 Year 2009 can be ruled out and the applicable regulations is the Law Number 6 of the Year 2018 and the Act No. 4 of 1984. In this case, apply a principle in the law, i.e., the Lex Specialis derogat legi generali. This principle refers to the two laws and regulations that hierarchically have the same position, but the scope of the substance between the two regulations was not the same, namely that one is a setting for special than others. Lex Generalis here is Law Number 36 Year 2009. While the Lex Specialis here is Law Number 6 of the Year 2018 and the Act No. 4 of 1984. So, in this context, vaccination can be a thing that is compulsory and anyone who hindered efforts in order to break the chain of transmission of Covid-19 (in this case is refused vaccination), then such person may be subject to sanctions.

b. With the announcement of the country in a state of emergency, then in this case the applicable Law of the State of emergency. That Staatsnoodrecht must meet three conditions, namely:

1. Action taken no other choice to save the country;

2. Statement of the country in a state of emergency pronounced in front of the parliament;

3. The action is temporary.

The principles of other highly related to the situation a state of emergency is a principle of salus populi suprema lex. This principle means that the safety of the people is the law of the highest. The implementation of the vaccination is in order to save the people of Indonesia itself.

c. Article 5 paragraph (3) of Law Number 36 Year 2009 on Health indeed gives the right to every person in terms of determining their own health services that are necessary for him. Even this Article also deals with the constitutional basis in Article 28H paragraph (1) of the constitution of the Republic of Indonesia Year 1945. However, it should be noted that the right of everyone even including the rights of a person was limited by the rights of others. In this regard, the Article 28J the constitution of the Republic of Indonesia Year 1945 stated as follows:

1. In the orderly existence of society, country, and state, everyone must respect the rights of others.

2. Everyone will be dependent upon the limitations forced by the Legislation in the activity of privileges and opportunities, with the sole motivation behind guaranteeing acknowledgment and regard for the privileges and opportunities of others, just as fulfilling the needs of a reasonable as per the pertimbangam moral, strict qualities, security, and public request in a majority rule society.

Vaccination is not only aimed to protect yourself, but also others to create immunity community (herd immunity). And other people also have the same rights to live a healthy life. So, in this case, vaccination should not be rejected.

d. At this second, there is no therapy for the ailment brought about by the infection Covid-19. Therefore, to stop the spread of Covid-19, the immunization technique is basic. Coronavirus inoculation tries to restrict Covid-19 transmission, diminish Covid-19 bleakness and demise, and accomplish local area wide crowd invulnerability, and shielding the local area from Covid-19 to remain socially and monetarily useful. Consequently, should the program immunization be not dismissed by the local area considering this is the underlying exertion to break the chain of transmission of Covid-19. 
e. Viewed from the point of view of the Science of the State, one of the properties of the essence of the state is to have the nature of the force. The state has the power to force even using violent or coercive. The nature of the force is intended to achieve the objectives of the state or national consensus. With regard to the process of vaccination, one of Indonesia as an example of a country that can do the compulsion to its citizens to follow the vaccination program, as the state also imposes upon its citizens to adhere to the protocol health. It is planned that the motivation behind the state set out in the Preamble to the constitution of the Republic of Indonesia Year 1945 to ensure individuals of Indonesia and the whole country of Indonesia (association here is to shield individuals of Indonesia from the infection Covid-19) can be accomplished.

f. The state is not necessarily able to commit acts of violence to achieve its goals. There are rights or civil rights that must be respected by a contracting state.

When you pay attention to the provisions in Article 28J paragraph (2), it is clear that the restriction of Human Rights is not restricted by law or consideration of the juridical but the limitation it is a constitutional based on considerations of the moral and religious values in order to protect and respect the rights and freedoms of the person/the individual and the community. Quote term of Prof. I Dewa Gede Atmadja, the article shows that applies the principle of "No Right of Freedom Without Limits". Article 28J can be said as a liability right. The assertion about the existence of the obligation rights, this becomes very important because since the reform era, with the excuse of human RIGHTS, there are many citizens who don't pay attention to the obligations of the essence as part of human-human other in the unity of the community.

Therefore, the implementation of vaccination in Indonesia can be a duty for every citizen. Indeed, there are someone's right to choose health care services for him. However, when seen with regards to the circumstance of the pandemic as of now, then, at that point, such privileges might be decreased to accomplish the objective of the state to secure every one individuals of Indonesia and furthermore incorporates ensuring the common liberties of an individual itself to gain the right to live in a solid way. Then from the above explanation, in the case of vaccination in Indonesia, there are a number of variables are interrelated. Which country in a state of emergency and the next is related to the obligations of the rights of man to appreciate the rights of others (in this case is the right to health of others).

\section{Conclusion}

The IPR selectiveness of the antibody Covid-19 isn't something that can be manhandled endlessly, yet the state may situate itself as a kind of obligation by forcing constrained permitting or uncovering exclusive data. That the Government needs to push for researchers to strive to do the best in order to find a vaccine Covid-19, which eventually Indonesia as a country that has a population of many not be a market. If eventually a vaccine is found from foreign parties, the application of the compulsory license is the appropriate step.

Vaccination in order to handle Covid-19 is a right and obligation of citizens of the country. Indeed, there are someone's right to choose health care services for him. However, when viewed in the context of virus-Covid-19-scale pandemic, as well as referring to that someone who is not a vaccine can actually potentially be a virus carrier for other people, then such rights may be reduced in order to achieve the objectives of the state which protects the entire Indonesian nation and the entire country of Indonesia (in this case, protect from the virus 
Covid-19), and also includes protecting the human rights of a person itself in order to acquire the right to live in a healthy manner. Therefore, vaccination in the beginning was a right for a person can be turned into an obligation given country in a state of emergency and the next is related to the obligations of the rights of man to appreciate the rights of others, in this case is the right to health of others.

\section{References}

[1] Bernard L Tanya, 2020, Teori Hukum Strategi Tertib Manusia Lintas Ruang dan Generasi, Genta Publishing, Yogyakarta.

[2] Cita Citrawinda Priapantja, 2003, Hak Kekayaan Intelektual: Tantangan Masa Depan, Badan Penerbit Fakultas Hukum Universitas Indonesia, Jakarta.

[3] Dedi Afandi, 2008, Hak Atas Kesehatan Dalam Perspektif HAM, Jurnal Ilmu Kedokteran, Jilid 2 No. 1.

[4] I Dewa Gede Atmadja, 2010, Hukum Konstitusi, Problematika Konstitusi Indonesia Sesudah Perubahan UUD 1945, Setara Press, Malang.

[5] Jimly Asshiddiqie, 2011, Konstitusi dan Konstitusionalisme Indonesia, Sinar Grafika, Jakarta.

[6] Komite Penanganan Covid-19 dan Pemulihan Ekonomi Nasional, 2021, Paked Advokasi, Vaksinasi Covid-19, Lindungi Diri, Lindungi Negeri, KPCPEN, Jakarta.

[7] Niken Prasetyawati Tony Hanoraga, 2015, Lisensi Wajib Paten Sebagai Salah Satu Wujud Pembatasan Hak Eksklusif Paten, Jurnal Sosial Humaniora 8.2.

[8] Peter Mahmud Marzuki, 2017, Penelitian Hukum, Kencana Prenadanamedia Group, Jakarta.

[9] Sefriani, 2017, Hukum Internasional Suatu Pengantar, Rajawali Pers, Jakarta.

[10] Sylvia Hasanah Thorik, 2020, Efektivitas Pembatasan Sosial Berskala Besar di Indonesia dalam Penanggulangan Pandemi Covid-19, Adalah: Buletin Hukum dan Keadilan 4.1.

[11] Tri Handayani, dkk, 2020, Pandemi Covid-19, Respon Imun Tubuh dan Herd Immunity, Jurnal Ilmiah Permas, Sekolah Tinggi Ilmu Kesehatan Kendal, Volume 10 No 3.

[12] Wibowo Hadiwardoyo, 2020, Kerugian Ekonomi Nasional Akibat Pandemi Covid-19, Baskara: Journal of Business \& Entrepreneurship 2.2.

[13] https://setkab.go.id/vaksin-segera-dimulai-presiden-3295-juta-dosis-vaksin-Covid-19telah-dipesan/ (diakses pada 25 Agustus 2021)

[14] https://setkab.go.di/menkes-sebut-vaksinasi-Covid-19-akan-dimulai-pekan-depan/ (diakses pada 25 Agustus 2021)

[15] https://www.law-justice.co/artikel/100970/natalius-pigai-menolak-vaksin-adalah-hakasasi-rakyat/ (diakses pada 25 Agustus 2021)

[16] https://setkab.go.id/pelaksanaan-vaksinasi-Covid-19-perdana-di-Indonesia-13-Januari2021-di-Istana-Merdeka-Provinsi-DKI-Jakarta/ (diakses pada 30 Agustus 2021) 